\title{
リモートセンシングデータを用いた森林樹冠率の推定 （京都議定書対応のためのリモートセンシング技術の確立）
}

\section{Estimation crown cover ratio with remote sensing data (The establishment of the remote sensing technique to contribute to the Kyoto protocol)}

\author{
小熊 宏 之* ・ 山形与志樹* \\ Hiroyuki OGUMA, Yoshiki YAMAGATA
}

\begin{abstract}
The Kyoto protocol was adopted in 1997. According to some definitional options, forest and non-forest area are distinguished using crown cover ratio. In order to delineate such forest regions, the development of the way to measure the crown cover ratio of forest is urgently necessary. In this study, various methods were tested for estimating crown cover ratio by using airborne spectral sensor data. Negative correlation coefficients were found among spectral bands of CASI in visible region and crown cover ratio. The best correlation coefficient was attained by the ratio of between $465 \mathrm{~nm}$ and $700 \mathrm{~nm}$ bands. Standard error was around $5 \%$ of the correlation. Whereas, the correlation coefficient was low by the NDVI which used often to estimate vegetation biomass. This research shows that the possibility to estimate the crown cover ratio accurately with optical remote sensing data.
\end{abstract}

\section{1.はじめに}

1997年に採択された京都議定書では，先進国におけ る温室効果ガスの排出削減に対する具体的な数值目標 が提示された。この京都議定書の 3 条 3 項において, 吸収源として規定された森林を京都フォレストと呼 び，1990年を基準年として，以降の直接的かつ人為的 に新規植林 (Afforestation), 再植林 (Reforestation), 森林減少（Deforestation）が行われた森林（地域）を 指す。すなわち1990年の基準年における土地被覆のう ち，以前「森林」だった土地に「再植林」した場合の $\mathrm{CO}_{2}$ 吸収，「伐採」による $\mathrm{CO}_{2}$ 放出，そして「森林」以 外の土地に「新規植林」することによる $\mathrm{CO}_{2}$ の吸収量 を，2008年から2012年の第一約束期間に見積もる必要 がある。従って1990年の「森林」・「非森林」の判別が 全ての基準となる。「森林」として認められる土地被覆 は, 将来的に樹高が $5 \mathrm{~m}$ 以上となる樹木が被覆し, 特

*国立環境研究所 地球環境研究センター

National Institute for Environmental Studies Center for Global Environmental Research

「写真測量とリモートセンシング」VOL. 39, NO. 2, 2000
定の範囲内 $(0.5 \mathrm{ha}$ 程度とされているが現状では未定) において, 樹冠を地表面投影した場合の面積比率を「樹 冠率」として，これがある閾值以上を满たしている部 分とされる (IPCCの特別報告書が準備されている)。 このような背景からリモートセンシングを用いて, 従 前から行われてきた樹種分類や森林伐採の抽出に加之 て, 樹冠率を正確に推定するための手法, 開発が喫緊 の課題となっている。更に，国外における新規植林で の $\mathrm{CO}_{2}$ 吸収量を算定することで，同量の $\mathrm{CO}_{2}$ 排出権と してクレジットが与えられる。ここでも $\mathrm{CO}_{2}$ 吸収量算 定に際しては，樹冠率は重要な項目であることから， 本研究ではリモートセンシングを用いた樹冠率推定の 可能性を検証することを目的として様々なケースス夕 ディを行った。まず，航空写真を用いた眓化作業によ ク，個々の樹冠をポリゴン化することで樹冠面積を求 め, 樹冠率を算出した。このように写真や地上調査に よる樹冠率のトゥルースは，ごく限定された領域で得 られるいわばポイントデータである。これにリモート センシングデータとの関係式が確立できれば, ポイン トデー夕を広域化することが可能となる。そこで, 航 空機搭載型の光学センサを用いて樹冠率と分光スペク トル情報との関係を求め, 樹冠率推定式を作成した。 更に衛星による観測のシミュレーションを行い, 過去 
の衛星データによる樹冠率推定の可能性について検討 した。

\section{2. 解析対象}

対象は釧路湿原内のハンノキ林を選んだ。同域にお けるハンノキ林は，樹冠面積や密度が伏流水など生育 環境の微妙な違いで大きく変化するため，樹冠が疎な 状態と密な状態を狭い範囲で得やすいこと，加えて傾 斜効果を考慮する必要が省略されること等からリモー トセンシングによる研究・検証サイトとして好適な対 象である。今回は樹高 $10 \mathrm{~m}$ 以上のハンノキが密集した 高木林をサイト 1 , 樹高 $3 \mathrm{~m}$ 以下の疎林部をサイト 2 とし，この 2 箇所について $200 \mathrm{~m} \times 200 \mathrm{~m}$ の領域を解析 対象とした。1992年 6 月に $1 / 5000$ スケールでオーバ ラップ $60 \%$ の条件で撮影された航空写真を用い，解析
図化機を用いた目視による計量と現地計測による校正 を行い, 全てのハンノキについて樹高を求めると同時 に，樹冠部分をポリゴン化することで樹冠面樍を求め た。図 1 はサイトの概要である。サイト 1 は 4426 本,

1 本あたりの平均樹冠面積が $3.3 \mathrm{~m}^{2}$, 平均樹高が $5.9 \mathrm{~m}$ に対して, サイト 2 が 2601 本, 平均樹冠面積 $2.4 \mathrm{~m}^{2}$, 平 均樹高は $1.7 \mathrm{~m}$ であった。

\section{3. 解 析}

CASI のデー夕取得は1994年 9 月 2 日に実施され た。ここでCASI とはカナダのItres 社製の航空機搭 載型イメージングスペクトロメータである。取得時の 諸元を表 1 に示す。観測は空間分解能を優先した spatial モードと，連続分光観測を行う spectral モードの 2 通り行われた。Spatial モードでは空間分解能が約
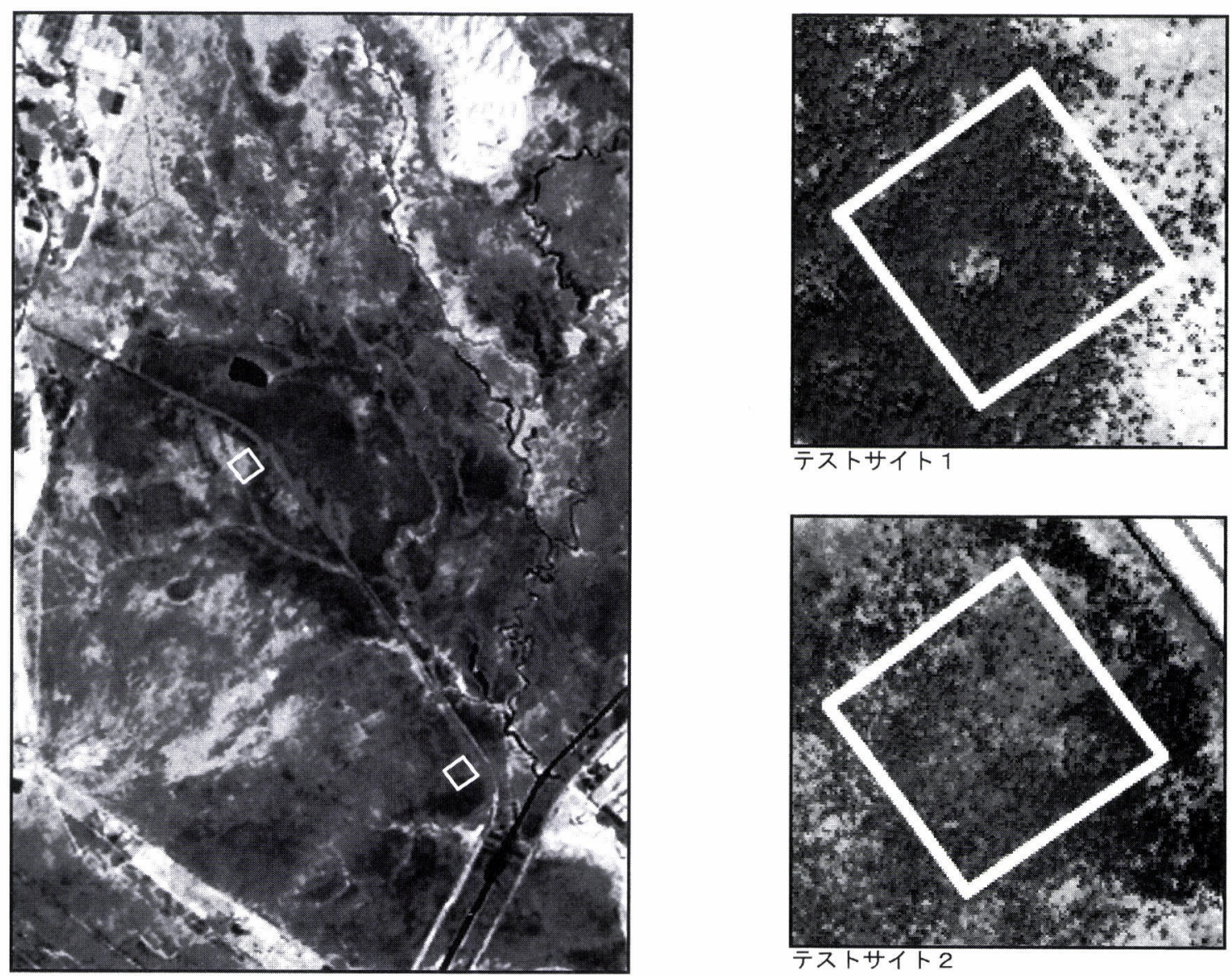

図 1 テストサイトの概要 左側はLANDSAT/TM 画像 (1993年 7 月 1 日撮影), 右側は各サイトの CASI (Spatial モード) 画像 
表 1 CASI による観測諸元

デー夕取得 1994年 9 月 2 日

飛行高度 $1600 \mathrm{~m}$

使用機体 Cessna206

量子化数 $12 \mathrm{bit}$

spatial mode

\begin{tabular}{ccc} 
バンド & 中心波長 $(\mathrm{nm})$ & 波長幅 $(\mathrm{nm})$ \\
\hline 1 & 465.4 & 11.0 \\
2 & 554.6 & 9.3 \\
3 & 599.9 & 11.1 \\
4 & 640.0 & 9.4 \\
5 & 659.7 & 9.3 \\
6 & 680.3 & 11.1 \\
7 & 700.0 & 11.2 \\
8 & 720.6 & 9.4 \\
9 & 749.5 & 9.5 \\
10 & 830.0 & 11.3 \\
\hline 地上分解能 & $1.9 \mathrm{~m}(\mathrm{swath}) \times 2.2 \mathrm{~m}($ track $)$ \\
データ取得時間 & $9: 47$ - $9: 53$
\end{tabular}

spectral mode

\begin{tabular}{ccc} 
バンド & 中心波長 $(\mathrm{nm})$ & 波長幅 $(\mathrm{nm})$ \\
\hline 1 & 403.2 \\
& 約 $5.4 \mathrm{~nm}$ 間隔連続分光 \\
96 & 913.0 \\
\hline
\end{tabular}

地上分解能

デー夕取得時間

$1.9 \mathrm{~m}($ swath $) \times 7.2 \mathrm{~m}($ track $)$

$11: 56-12: 02$

$2 \mathrm{~m}$ と,ハンノキの樹冠を特定することが可能な分解 能である。ただし取得できるバンド数は, 波長分解能 が約 $10 \mathrm{~nm}$ の10バンドに限定される。一方 Spectral モ一ドは波長分解能 $5 \mathrm{~nm}$ の96バンドの連続分光デー 夕が取得できるが, 空間分解能が $2 \mathrm{~m} \times 7 \mathrm{~m}$ (進行方 向）と変則的となる。なお，樹冠面積を算出した航空 写真の撮影と CASI のデータ取得は 2 年間異なるが, 湿地植生では 2 年間の成長量は大きくなく, 解析には 差し支えないものと判断した。次に両サイトにおける ハンノキをポリゴン化した画像に対し CASI 画像の重 ね合わせを行った。Spatial モ一ドの幾何補正には GCP として樹冠が CASI の 1 画素程度で, 群集してい ない個所のハンノキを用い， 2 次のアフィン変換式に より䛊差 1 画素以内の合わせこみを行った。Spectral モードの幾何補正も基本的にはハンノキの樹冠を用い たが，ハンノキの特定が困難であることから誤差は CASI 画素にして1.5画素程度となった。

次に京都議定書における樹冠率とは，ある面積 $(0.5$ ha 程度とされているが現状では未定)の領域の中に樹

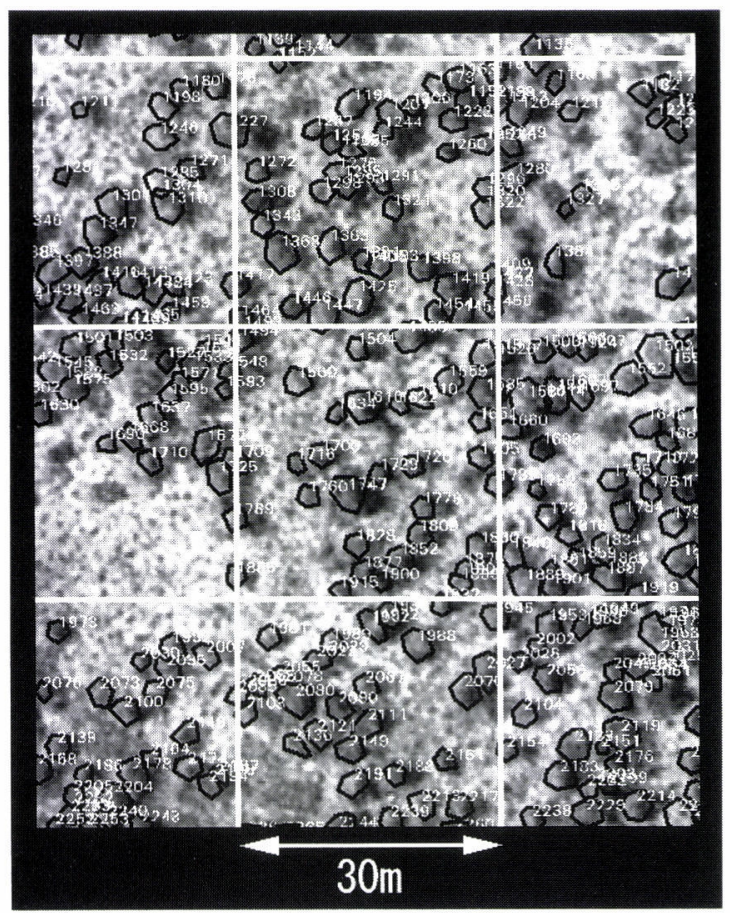

図 2 メッシュ化作業の一例 白線は30m メッシュ, 樹冠 部分を特定し黒線のポリゴンで示している

冠を地表面へ投影した場合の面積比率とされている。 LANDSAT/TM など衛星センサの利用を想定する と, 1 画素内で樹冠率が推定できることが必要である。 そこで解析の最小単位として $10 \mathrm{~m}, 20 \mathrm{~m}, 30 \mathrm{~m}$ の 3 条件 のメッシュを設定し，メッシュ内に入るハンノキの全 ての樹冠面積を求め, メッシュ単位の面積で除するこ とで樹冠率とした。これに対し，1メッシュ内の全 CASI 画素の平均 DN (Digital Number, 以下 DN) 值 を求め, 1 メッシュ内の代表 DN 值とし, 樹冠率との 比較を行った。メッシュ化作業の一例を図 2 に示す。

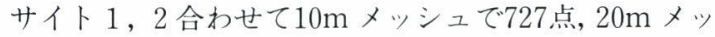

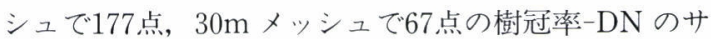
ンプルを得な。なお, spectral モードのデー夕は空間分

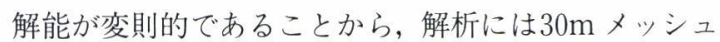
の值だけを用いることとした。解析内容について以下 に列挙する。

1) CASI の単バンドを用いた場合と, 全ての組み合 わせ方によるバンド間比演算を行った場合の回帰分析 を行い，樹冠率推定に有効となる観測バンド・組み合 わせ方を選定し樹冠率推定式を求めた。また比演算の 回帰分析に加えて，植生現存量推定の方法として用い 
られる NDVI(正規化差分植生指数) の有効性を検証 した。

2 ）現実的には樹冠率の実測值が整備できる範囲は極 めて狭い範囲に限定され，そこで確立された推定式を 用いて，広範囲かつ大きいメッシュにおける樹冠率を 推定することが必用となる。その場合, 変換式を求め るために十分なサンプル点数を得るためには小さい メッシュ単位で集計し，得た推定式を広範囲に外挿す ることが求められる。このような状況を想定し，10m

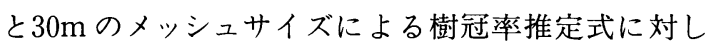
て同一のセンサ観測値を代入し，得られた樹冠率の比 較を行った。

3 ) これまでは，サイト $1 ， 2$ 全てのデータを用いて 推定式を求めたが，仮に対象としている樹木の生育状 態や，粗密の程度などが偏った場所でのみ推定式を作 成し，他の場所に適用させた場合に生じる問題を明ら かにするため，ここではハンノキが密な状態のサイト 1だけを用いて樹冠率推定式を作成し，これをハン， キが疎であるサイト 2 に適用した場合の標準䛊差を求 めた。

4 ）京都議定書では森林変動の抽出を1990年を基準年 としてカウントする，既に10年経過している1990年当 時の森林の樹冠率を広域に推定するためには，当時の LANDSAT PSOT などの衛星データや1990年に撮 影された航空写真を用いる以外に手段は無い。HRV は高分解能のパンクロモードを持つが， $10 \mathrm{~m}$ の空間分 解能では樹冠を直接捕らえるのは不可能であり，スぺ クトル情報による樹冠率の推定方法を検討する必要が ある。TM や HRV は CASI の $10 \mathrm{~nm}$ 以下の分光幅に 対して60-80nm 程度の波長分解能である。そこで CASIのスペクトラルモードによるデータを用いて LANDAT/TM とSPOT/HRV の観測バンドのシ ミュレーションデータを作成し, 樹冠率の推定を行っ た。なお, HRV は空間分解能が $20 \mathrm{~m}$ であるが spectral

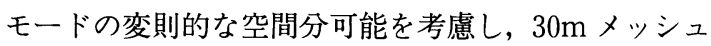
だけを用いた。衛星センサの各バンドの半值幅に合わ せてCASIの $5 \mathrm{~nm}$ 連続分光デー夕を平均化し観測シ ミュレーションデータを作成した。なお，センサ個別 の分光感度曲線は考慮していない。更に TMについて は, CASI が観測出来ない波長領域であるバンド 5 , 6，7 は対象外とした。ここでの解析は，CASIによる 解析と同様，単バンドを用いた場合，NDVI 值と更に 全てのバンドの組合せによる比演算を行い，樹冠率と
の相関係数を求めた。

なお，樹冠率推定には CASI の高分解能画像を用い たカテゴリー分類により樹冠を直接特定し，メッシュ 毎に集計するといったアプローチも考えられるが，衛 星デー夕利用の可能性を検証する目的には相応しくな く, 本解析ではメッシュ毎の樹冠率と平均スペクトル 值との解析に限定した。

\section{4. 結果と考察}

\section{1 樹冠率とスペクトルの相関}

図 3 は CASIの spatial モードの DN と30mメッ シュ内の樹冠率との相関関係である。青バンドを除く 可視域の DN と樹冠率との間には強い負の相関が認 められる一方，近赤外バンドとの相関は概ね低い值と なっている。最も高い相関関係は700nm の-0.89であ $\eta$, 次いで $600 \mathrm{~nm}$ バンドの $-0.86,640 \mathrm{~nm}$ のバンド -0.85となった。またクロロフィルの吸収の極大であ る赤 $(680 \mathrm{~nm})$ 付近では相関係数が -0.68 と若干低下す る。図 4 には $10 \mathrm{~m}$ メッシュにおける樹冠率 $5 \%$ 以下と $55 \%$ 以上の場合について，680nm 前後の CASI の DN を比較したものである。他のバンドに比較して, $680 \mathrm{~nm}$ バンドの変化はわずかである。クロロフィルの吸収帯 は，ハンノキと林床植生は共に同一波長付近であると 考えられることから，メッシュ内におけるハンノキの 樹冠率の大小に関わらず吸収が飽和しており，相関係

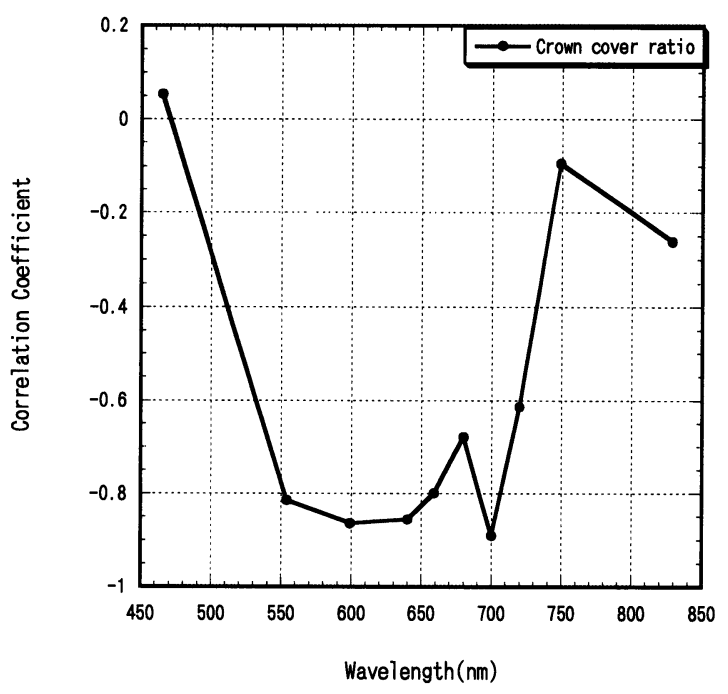

図 $330 \mathrm{~m}$ メッシュ内の樹冠率と CASI による分光放射輝 度值との相関関係 


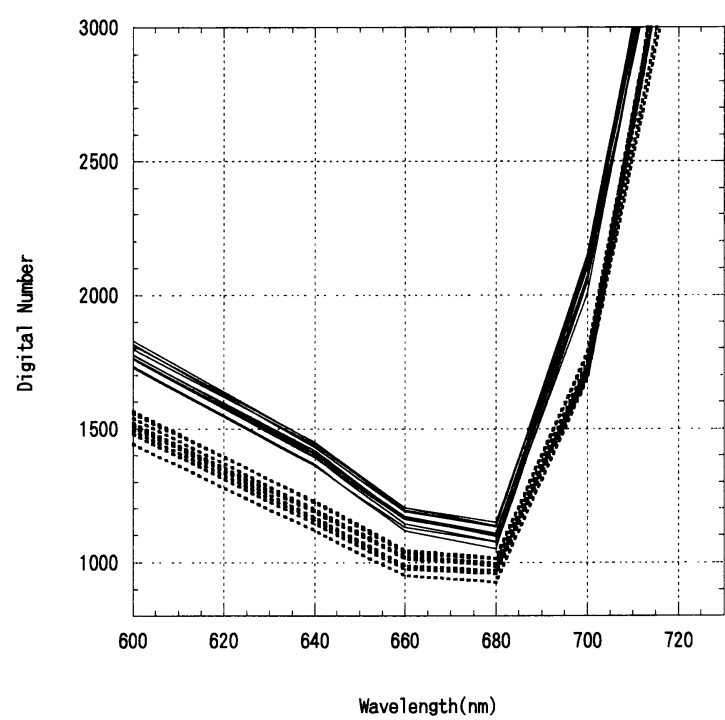

図 4 樹冠率が $5 \%$ と5\%の条件での CASI 観測值の違い 実線が樹冠率 $5 \%$, 破線が樹冠率55\%を示す

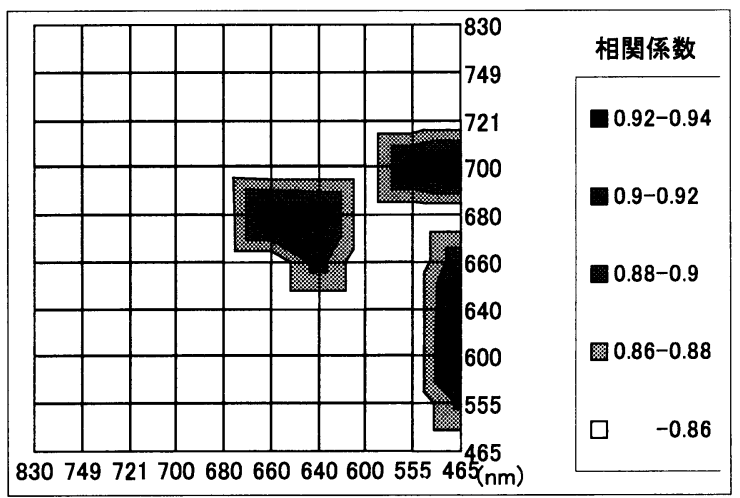

図 5 バンドの比演算による值と樹冠率の相関関係

数が低下する原因として考えられる。次に10バンド全 てを総当りした比演算処理による結果（図 5 ）では, 単バンドの場合には最も相関係数が低かった $465 \mathrm{~nm}$

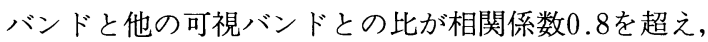
$700 \mathrm{~nm}$ と $465 \mathrm{~nm}$ バンドの比が相関係数 0.93 と最も高 く, 次いで $640 \mathrm{~nm}$ と $465 \mathrm{~nm}, 700 \mathrm{~nm}$ と680nm の順に高 い相関係数が得られた。 $465 \mathrm{~nm}$ バンドと他の可視バン ドとの比演算で高い相関係数を得ることが出来る理由 として，赤領域と同じくクロロフィルの吸収のピーク 波長であること，単バンドの結果では465nmバンドの みが弱い正の相関を示したことなどが考えられるが, 詳細な解析は今後の課題としたい。

一方，多くの植生指数は可視域の赤領域バンドと近 $-86-$

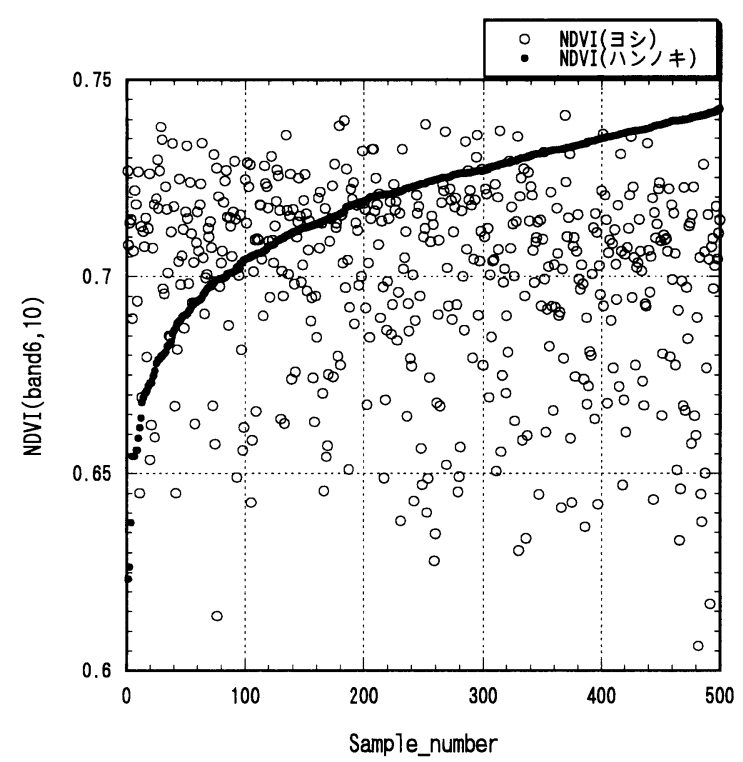

図 $6 \mathrm{CASI}$ の画素から求めたハンノキとヨシの NDVI 值 の比較

赤外バンドの比演算を基本としているが，近赤外バン ドの750nm または $865 \mathrm{~nm}$ バンドと, 全ての可視バンド の比演算では高い相関係数を得ることが出来なかっ た。植生指数としては NDVIが一般的に用いられてい るが, $865 \mathrm{~nm}$ バンドと680nm バンドから求めた NDVI 值と樹冠率の相関は低い。ハンノキの樹冠率が低い メッシュでは, 草本植生としては釧路湿原最大のバイ オマス量であるヨシが繁茂している。図 6 は，樹冠面 積が CASI 画素より大きい $5 \mathrm{~m}^{2}$ 以上のハンノキだけ を選別し, CASI 画素から求めた NDVI 值と, その近 傍画素におけるヨシ群落上の NDVI值を比較したも のである。比較を容易とするため，ハンノキの NDVI 值のみをソートした。概ねハンノキの NDVI はヨシに 比較して高めではあるが明確には分離せず，ヨシの NDVI 值がハンノキより上回る場合がある。このた め, NDVI值の閾值を設定するのみではハンノキと林 床植生を分離することは不可能であり, これが樹冠率 との相関が低い原因と考えられる。すなわち植林直後 など樹冠率が低く, 林床植生の露出が十分ある地域で, かつ両者の成育がピーク時には NDVI だけで樹冠率 を評価することは誤差を生じる可能性があり, 樹冠率 を正確に推定するためには対象植生の他に林床植生な ど観測メッシュ内に混入する他の植生の影響を考慮し たスペクトルモデルを用いる必要があると言える。 


\section{2 メッシュサイズと推定式の関係}

10，20，30mの 3 条件のメッシュサイズにおいて， 最も高い相関係数は $465 \mathrm{~nm}$ バンドと $700 \mathrm{~nm}$ バンドの 比演算による值であった。メッシュサイズが大きくな ることに伴い樹冠率推定式の係数には僅かな変動が見 られる(図 7 )。この係数の違いを樹冠率の推定値で比 較すると，10mメッシュで求めた推定式において樹冠

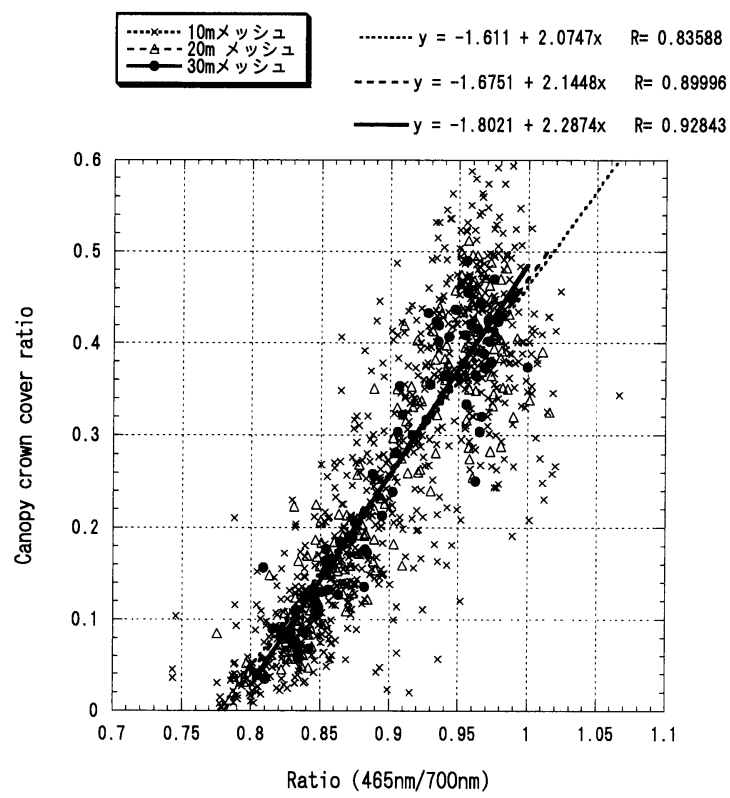

図 7 メッシュサイズ別の樹冠率と CASI バンド 1 と 7 の 比演算による值との関係

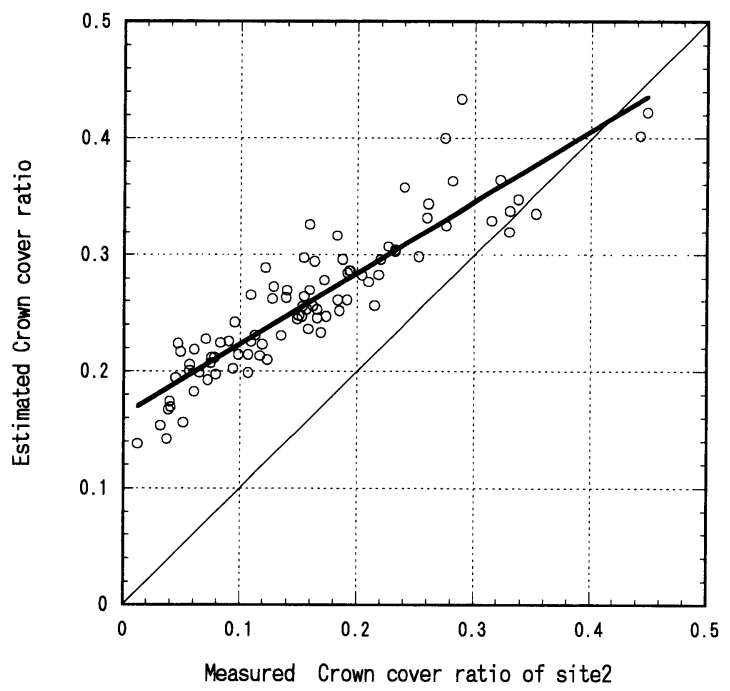

図 8 サイト 1 のみで得られた樹冠率推定式をサイト 2 の CASI 観測值に用いた場合の推定值
率を10\%とする DN を30m メッシュでの推定式に代

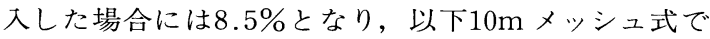
$20.4 \%$ の場合に $30 \mathrm{~m}$ メッシュで19.9\%，10m メッシュ で $40.1 \%$ の場合に $30 \mathrm{~m}$ メッシュでは $41.6 \%$ となり，樹 冠率に変換した場合の差は僅かである。これは $10 \mathrm{~m}$ メッシュで推定式を作成し，最終的に集計する単位へ の適用が可能であることを示す。すなわち樹種や林床 の植生あるいは傾斜等の条件が変わらない範囲におい ては，限定された場所で求められた樹冠率推定式を， 低空間分解能画像による広域推定に適用可能であると いうことが出来る。

\section{3 トレーニングエリア選定の問題}

$20 \mathrm{~m}$ メッシュのデー夕を用い，サイト 1 において， $465 \mathrm{~nm}$ と700nm のバンド比演算による樹冠率推定式 を求め，これをサイト 2 における CASI デー夕に適用 した。すなわちハンノキが密な状態でのみ推定式を求 め，これを用いて疎な状態の推定を行うことになる。 図 8 は縦軸に樹冠率の推定值, 横軸に測定值を示して いる。この例からは，樹冠率が低いプロットでは $10 \%$ 以上の過大推定をしてしまう。逆に推定式を求めた状 況に近い，樹冠率の高いプロットでは推定誤差が小さ くなる傾向がある。すなわち推定式を求めたトレーニ ングサイトの樹冠率分布範囲を超える領域での推定に は注意が必要であることが分かる。

\section{4 衛星シミュレーションデータによる推定精度}

ここでは単バンド, NDVI, 全てのバンドによる比演 算を行い樹冠率との相関係数を求めた。図 9 に示すよ うに単バンドによる比較では，TM·HRV シミュレー ションともに緑から赤にかけての可視域のバンドと樹 冠率は高い負の相関を示している。逆に近赤外域のバ

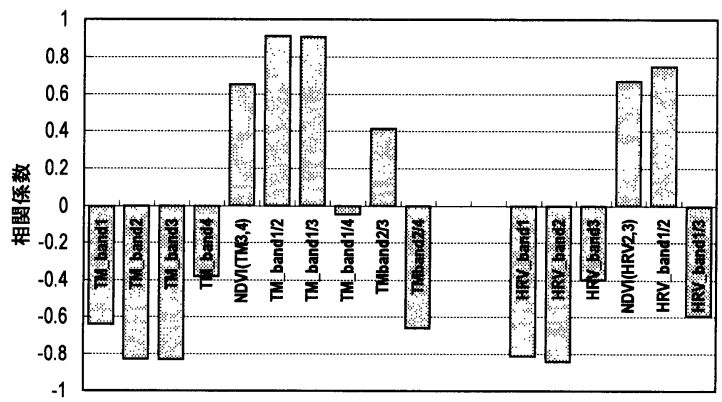

図 9 CASI の Spectral mode データを用いた TM と HRV シミュレーションによる樹冠率との相関関係 


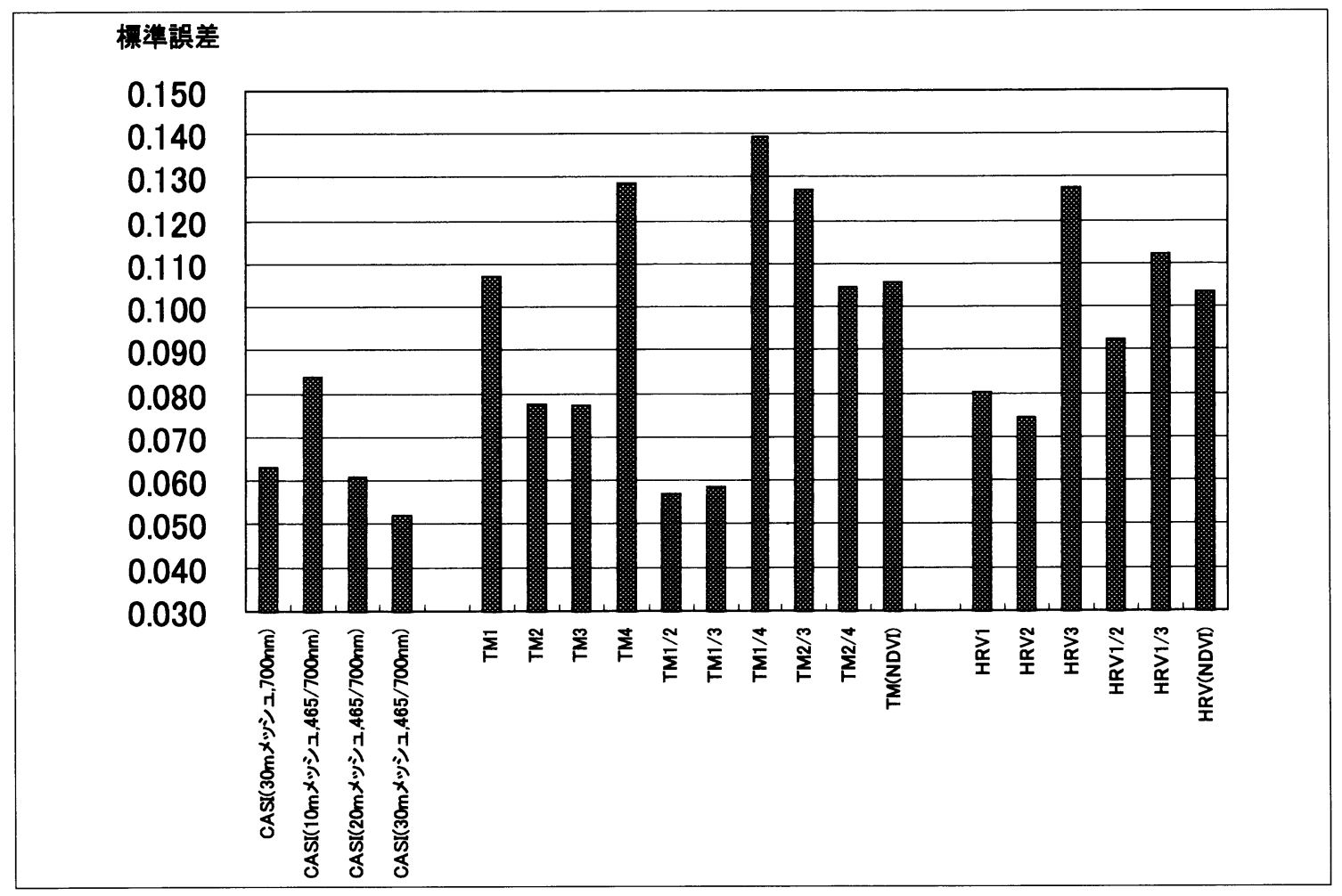

図10 樹冠率推定時における標準誤差の比較

ンドとの相関は低い。更に比演算の結果では, TM の band 1 (485nm)/band2 (560nm), 次いで, band1/band3 $(660 \mathrm{~nm})$ が高い正の相関を得られている。青バンドを 持たないHRVの結果では相関係数はTMより低め となり，単バンドよりも比演算を行った場合の相関係 数が低い值となった。一方でNDVI 值と樹冠率の間に は高い相関を認めることは出来ず, 複数の植生が混在 している場合, 特定対象の樹冠率を NDVI だけで評価 することにはやはり限界があることが判明した。また， CASIの spatial モードによる結果と比較した場合, 前 者は波長分解能が10nmであり, 衛星センサシミュ レーションでは $60 \mathrm{~nm}$ 以上の波長分解能となっている が，相関係数が大きく低下することはなかった。

\section{5.まとめ}

航空写真の困化作業により算出した樹冠率をトゥ ルースとし, 航空機センサ CASI を用いてスペクトル 情報から樹冠率を推定する可能性について検証した。 樹冠率は概ね可視域のバンド出力と負の相関関係にあ $\eta$, 近赤外域との相関は低いものとなった。最も樹冠 率の推定精度が高かったのは, $465 \mathrm{~nm}$ と700nm の比演 算であった。図10は，1) CASI 単バンド，2）樹冠率 推定式によるメッシュサイズ別，3）衛星センサシ ミュレーション, の各デー夕を用いて樹冠率を推定し た際の標準誤差を比較したものである。CASI の spa-

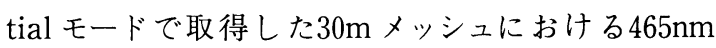
と700nm (ともに $10 \mathrm{~nm}$ の分光幅) の比演算による推定 が最小の標準誤差5.2\%であった。次いでCASIの spectral モードの連続分光デー夕を用いてシミュレー トしたLANDSAT/TM の観測バンドの band1 (485 $\mathrm{nm}) / \mathrm{band} 2(560 \mathrm{~nm})$ による $5.7 \%$, band1/band3 $(660$ $\mathrm{nm})$ の5.9\%の標準誤差であった。CASIの spatial モードのオリジナル波長分解能である $10 \mathrm{~nm}$ デー夕を 用いた比演算のバンド組み合わせと TM のバンドを シミュレート $(60 \mathrm{~nm} \sim 80 \mathrm{~nm})$ したデータによる比演算 バンドの組み合わせは, 共に青領域と, 緑又は赤領域 のバンド組み合わせによる樹冠率推定式からよい結果 を得ることが出来た。更に, 波長分解能 (半值幅) が 10倍以上低下しても標準誤差には大きな差として現れ 
ず，むしろ中心波長が重要な要因であった。一方で, 植生現存量と相関があるとされている植生指数 NDVI と樹冠率の間には高い相関は見られなかった。 着目すべき対象 (森林) と林床植生が生育のピーク状 態である場合にはNDVIのみで評価を行うことは困 難である。更に，樹冠率推定に有効とされた波長や推 定式は, 対象森林の樹種, 林床植生種, デー夕取得時 期，更に林床の土壤色や湿潤性などがスペクトル情報 に大きな影響を与える事が予想され，状況に応じた有 効な推定手法・係数等を求めていく必要があると考え られる。

\section{謝 辞}

本解析に用いた航空写真及びCASI デー夕は宇宙開 発事業団との共同研究「気候遷移地域における環境変 化解析手法の研究」において取得された。また本解析 に際しては株式会社パスコの島崎彦人氏に多大なるご 協力を頂いた。関係者各位に感謝致します。

(受付日1999.11.12, 受理日2000.3.21)

\section{参考文献}

1) KYOTO PROTOCOL TO THE UNITED NATIONS FRAMEWORK CONVENTION ON CLIMATE CHANGE（京都議定書)，1997

2) DRAFT CHAPTER 4-IPCC SPECIAL REPORT DEFINITIONAL SCENARIOS ARTICLE 3.3, 1999

3 ）六川ほか, 温室効果ガス削減問題における今後の リモートセンシングの役割, 日本リモートセンシン グ学会第25回学術講演会, pp77-80, 1998 山形ほか，京都フォーレストの計測におけるリモー トセンシングデータの高度利用, 日本リモートセン シング学会第26回学術講演会

4 ）土屋ほか，空中写真を用いた樹高と林分密度の測 定手法と適用例，日林誌，81( 3)，1999 